\title{
A study of epidermal leaf anatomy of 18 Euphorbia taxa from Kerman Province, Iran
}

Seyed Mehdi Talebi*,

\section{Mitra Noori,}

\section{Habibeh Afzali Naniz}

Department of Biology,

Faculty of Science, Arak University,

Arak 38156-8-8349, Iran

\begin{abstract}
Euphorbia is the largest genus of Euphorbiaceae widely distributed all over the world. The genus members grow naturally in different parts of Iran and nearly 96 species of Euphorbia have been listed in the country. Investigations show that the traits of foliar epidermis have taxonomic values. That is why the features of epidermal leaf anatomy of 18 Euphorbia taxa were studied in the present study. Plant samples were collected from Kerman Province, Iran, and identified using available references. Semi-permanent slides were prepared of adaxial and abaxial leaf epidermis. Then the slides were studied using light microscopy and some epidermal leaf anatomy characteristics stomata types, trichomes, the shape and type of epidermal cell, and their walls were examined. Photomicrographs were taken from each sample. Results showed that stomata type were stable among the species. Not only leaf epidermal cell shapes differed between the taxa, but also in some species they varied between the abaxial and adaxial surfaces. These conditions hold true for cell wall patterns. Some of the studied taxa had simple and uniseriate trichomes on the epidermal surfaces, in most of them trichomes were present on both leaf surfaces, while in one species trichomes were seen on the abaxial surface. Our findings confirmed that some of the anatomical traits, such as the absence or presence of trichomes, epidermal cell shape, and anticlinal cell wall patterns had taxonomic value and are useful in the identification of taxa.
\end{abstract}

Keywords: Euphorbia, leaf anatomy, epidermis, taxonomy

\section{INTRODUCTION}

The genus Euphorbia, which comprises nearly 2000 species in the world (Govaerts et al., 2000), is one of the largest genera of angiosperms (Frodin, 2004). Members of the genus grow in all temperate as well as tropical regions, occur in a wide range of habitats, and show great variations in forms of growth. These plants vary from an-

*Corresponding author. E-mail: seyedmehdi_talebi@yahoo.com nual weeds to perennial trees that have a unique structure of their flowers. However, it is a cosmopolitan genus and has many taxa in non-tropical regions such as southern USA, South Africa, the Mediterranean Basin, and the Middle East (Zahra et al., 2014).

Ninety-six species of this genus were recorded in Iran by Rechinger and Schiman-Czeika (1964). These taxa have been classified into five sections (Anisophyllum Haw., Diacanthium Boiss., Triucalli Boiss., Sclerocyathium, and Tithymalus Boiss) 
based on morphological traits, but a recent molecular study of Riina et al. (2013) showed that the traditional classification of species into sections is not correct and does not show the phylogeny relationship of species.

During the last decades a remarkable evolution has occurred in the anatomical study of vascular plants and its applications in taxonomy (Ahmad et al., 2010). Metcalfe and Chalk (1979) stated that the anatomical features of Euphorbia show a wide range of differentiations in relation to the habitat diversity and that any prominent trait does not occur throughout the numerous tribes into which the family is divided.

Epidermal characteristics of plants were chosen because they are mildly influenced by ecological conditions and are of high diversity in structure (Bartholott, 1981). Former studies (e.g., Cutler, 1979; Ogunkunle, Oladele, 2000; Abubakar, Yunusa, 1998) showed that epidermal characteristics are also reliable in plant systematics and classification.

Zahra et al. (2014) investigated eight leafy species of Euphorbia for differences in the features of foliar epidermal anatomy. Furthermore, leaf epidermal features of 150 species of Euphorbia were examined by Kakkar and Paliwal (1974). Their study showed that papillae in different shapes and sizes were found on these cells. In addition, various types of stomata as well as epidermal cell shapes have been recorded. Therefore, we carried out an investigation on the leaf epidermal characteristics of eighteen Euphorbia taxa. The main propositions of the study were: identification of the most important anatomical traits of the leaf epidermis, and determining whether these characteristics are important in identifying taxa and whether they have taxonomic value for infrageneric classification.

\section{MATERIALS AND METHODS}

In the present study, epidermal traits of leaves of eighteen species/subspecies of Euphorbia were examined. The above-mentioned taxa belong to eight sections (Table). The sectional classification used in this study was based on Riina et al. (2013).
Samples of their natural populations were collected from different regions during spring 2015 and identified on the basis of available references, such as Flora Iranica (Rechinger, Schiman-Creika, 1964), and Flora of Turkey (Davis, 1967). The herbarium specimens were deposited in the Arak University herbarium.

For examination segments of leaflets from herbarium material, about $5 \mathrm{~mm}$ in diameter, were soaked in water overnight and then dried at room temperature after blotting with filter paper. After that the leaves were soaked in $30 \%$ nitric acid at room temperature for $48 \mathrm{~h}$. Then the epidermis of both abaxial and adaxial surfaces was removed with tweezers, washed in running water, stained in $1 \%$ Safranine and mounted in $10 \%$ glycerin for semi-permanent mounting (Widuri, Welzen, 1998). Some characteristics of epidermal leaf anatomy such as crystal, stomata types, trichomes, shape and type of epidermal cells and their walls were examined using Leica Galen III light microspore monitoring. Then photomicrographs were taken from each sample.

\section{RESULTS}

In all of the studied taxa, leaf stomatal types were seen as anisocytic. The shapes of leaf epidermal cells varied among the studied species and were recorded as polygonal (e.g., E. aleppica, E. cheiradenia, E. connata, E. densa, E. esula (Fig. 1, A-J), E. virgata, E. falcata subsp. macrostegia, E. helioscopia, E. hebecarpa, E. heteradena (Fig. 2, A-J), E. teheranica, and E. rhabdotosperma, Fig. 3, A-D), ameboid (E. orientalis, Fig. 3, E, F), rounded-polygonal (E. microsciadia, Fig. 3, G, H). In some of the studied taxa their shapes differed between adaxial and abaxial surfaces. For example, adaxial epidermal cells shapes in E. peplus, E. falcata subsp. falcata, and E. turcomanica were polygonal, but these cells were amoeboid, folded and amoeboid in the abaxial surface (Fig. 4, A-F).

The pattern of the anticlinal walls of epidermal cells varied among the studied taxa. Their shapes were straight in E. orientalis (Fig. 3, E, F) and E. szovitsii, semi-straight in E. falcata 
Table. Infrageneric classification and localities of the studied taxa of Euphorbia

\begin{tabular}{|c|c|c|}
\hline Section/subsection & Taxa & Habitat \\
\hline Myrsinites & E. aleppica $\mathrm{L}$. & Kerman Province, Bardsir-sang-e sayyad, $2500 \mathrm{~m}$ \\
\hline Pithyusa & $\begin{array}{l}\text { E. cheiradenia Boiss. \& } \\
\text { Hohen. }\end{array}$ & Kerman province, Rabor, Rosskeen, $2605 \mathrm{~m}$ \\
\hline Calyptratea & E. connata Boiss. & Kerman province, Kerman, $1712 \mathrm{~m}$ \\
\hline $\begin{array}{l}\text { Herpetorrhizae } \$ O P- \\
\text { positifoliae }\end{array}$ & E. densa Schrenk & Kerman province, Bardsir, Bahramjerd, $2079 \mathrm{~m}$ \\
\hline Esula & E. esula Auct-Orient & Kerman province, Rabor, Nanizolya, $2418 \mathrm{~m}$ \\
\hline Pithyusa & $\begin{array}{l}\text { E. falcata L. subsp. } \\
\text { falcata }\end{array}$ & Kerman province, Rabor twon-Nanizolya, 2418 m \\
\hline Pithyusa & $\begin{array}{l}\text { E. falcate L. subsp. mac- } \\
\text { rostegia. }\end{array}$ & Kerman province, Rabor, Nanizolya, 2418 m \\
\hline Helioscopia & E. helioscopia L. & Kerman province, Rabor, Nanizolya, $2418 \mathrm{~m}$ \\
\hline Esula & E. hebecarpa Boiss. & Kerman province, Bardsir, Ardigan, $3058 \mathrm{~m}$ \\
\hline Chylogala & $\begin{array}{l}\text { E. heteradena Jaub. \& } \\
\text { Spach. }\end{array}$ & Kerman province, Bardsir, Qaleasgar, $2673 \mathrm{~m}$ \\
\hline Pithyusa & E. microsciadia Boiss. & Kerman province, Baft, Plain Baft, $2238 \mathrm{~m}$ \\
\hline \multirow[t]{2}{*}{ Helioscopia } & E. orientalis $\mathrm{L}$. & Kerman province, Rabor- Rosskeen village, $2605 \mathrm{~m}$ \\
\hline & E. peplus L. & Kerman province, Shahrbabak, $1855 \mathrm{~m}$. \\
\hline Helioscopia & $\begin{array}{l}\text { E. rhabdotosperma } \\
\text { Radcl.-Sm. }\end{array}$ & Kerman province, Rabor, Nanizolya village, $2418 \mathrm{~m}$ \\
\hline Szovitsiae & E. szovitsii Fisch. \& Mey. & Kerman province, Rabor-shah peak, $2984 \mathrm{~m}$ \\
\hline \multirow[t]{2}{*}{ Pithyusa } & E. teheranica Boiss. & Kerman province, Rabor, Kangerii, $2433 \mathrm{~m}$ \\
\hline & E. turcomanica Boiss. & Kerman province, Rabort, Kander, $2186 \mathrm{~m}$ \\
\hline Esula & E. virgata Auct. Orient. & Kerman province, Rabor, Nanizolya, $2418 \mathrm{~m}$ \\
\hline
\end{tabular}

subsp. macrostegia and E. helioscopia (Fig. 2, C-F), and curved in E. aleppica, E. cheiradenia, E. connata, E. densa, E. esula (Fig. 1, A-J), E. virgata (Fig. 2, A, B), E. hebecarpa, E. heteradena (Fig. 2, G-J), E. Teheranica (Fig. 3 A, B), and E. microsciadia (Fig. 3, G, H).

In some taxa, the shape of anticlinal walls differed between abaxial and adaxial surfaces. Abaxial anticlinal walls in E. rhabdotosperma were semi-straight, but their adaxial shapes were curved (Fig. 3, C, D). Furthermore, adaxial anticlinal walls were found to be curved in E. peplus, E. turcomanica, and E. Falcate ssp. falcata (Fig. 4, A-F), while the shapes of abaxial anticlinal walls were straight in the mentioned species.

Some of studied taxa had trichomes on their leaf surfaces. All of the observed trichomes were uniseriate and non-glandular. These species were divided into two groups: in one group
(E. connata, E. microsciadia, E. turcomanica, and E. helioscopia) trichomes were present on both abaxial and adaxial surfaces (Fig. 5, A-E), but in the other group, which included E. rhabdotosperma, the hairs were only seen on the abaxial surface (Fig. 5, F).

\section{DISCUSSION}

Different studies (Metcalfe, Chalk, 1979; Evert, 2006) proved that anatomical investigations of the leaf epidermis revealed many interesting epidermal traits that have taxonomic value. In some dicotyledon species the epidermal cells surround guard cells directly. These cells are indistinguishable from their neighbours both in their morphology shape and in the nature of the cell content. Meanwhile, in other taxa the cells in contact with the guard cells are 


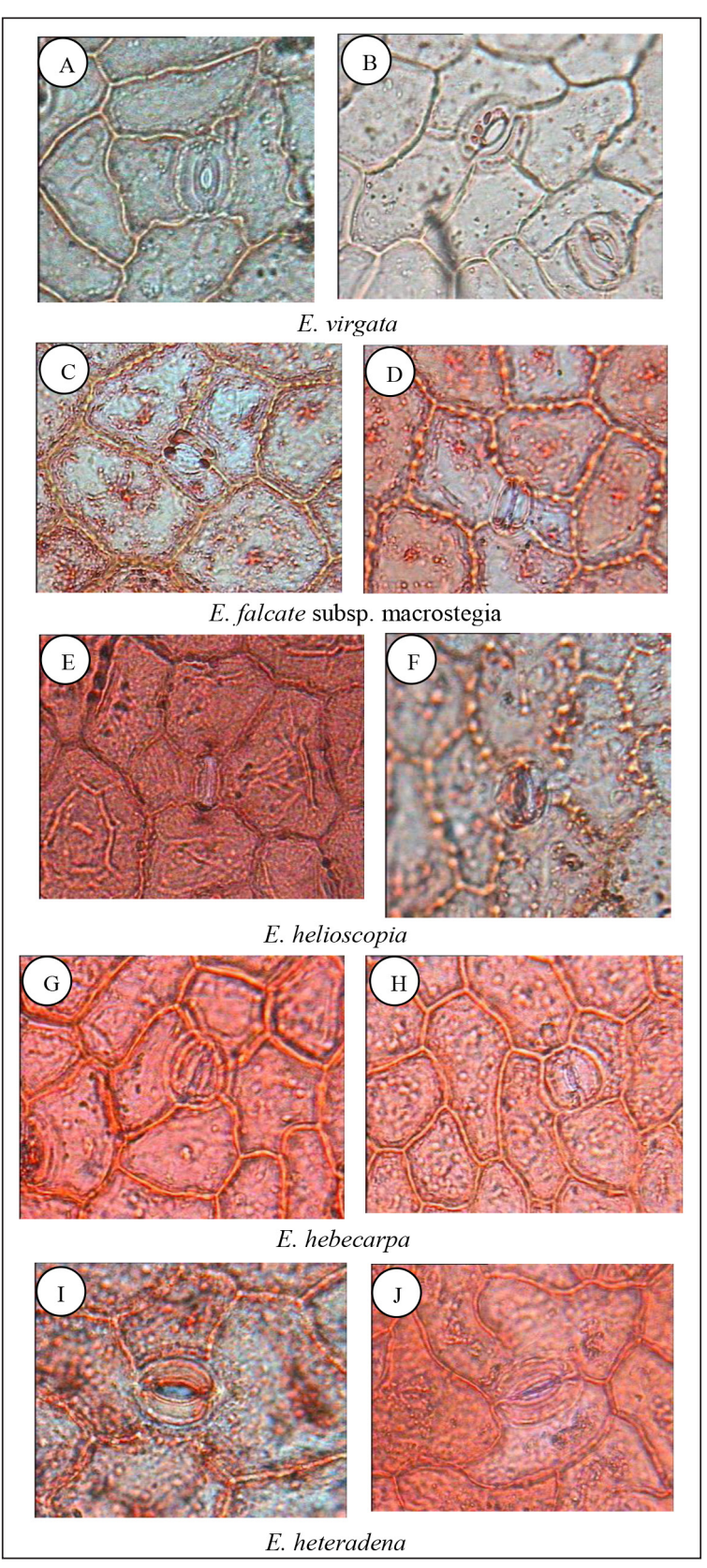

Fig. 1. Light images of leaf epidermis of the studied $\operatorname{taxa}(10 \mathrm{X})$

morphologically distinctive because of their forms, dimensions, and also orientation in relation to the guard cells. Therefore, stomata are classified into different types on the basis of shapes and arrangement of subsidiary cells. Our findings showed that stomata in all samples of the studied taxa were similar and looked anisocytic. In this form three epidermal cells surround stomata, but one of them is usually smaller than other cells (Metcalfe, Chalk, 1979).
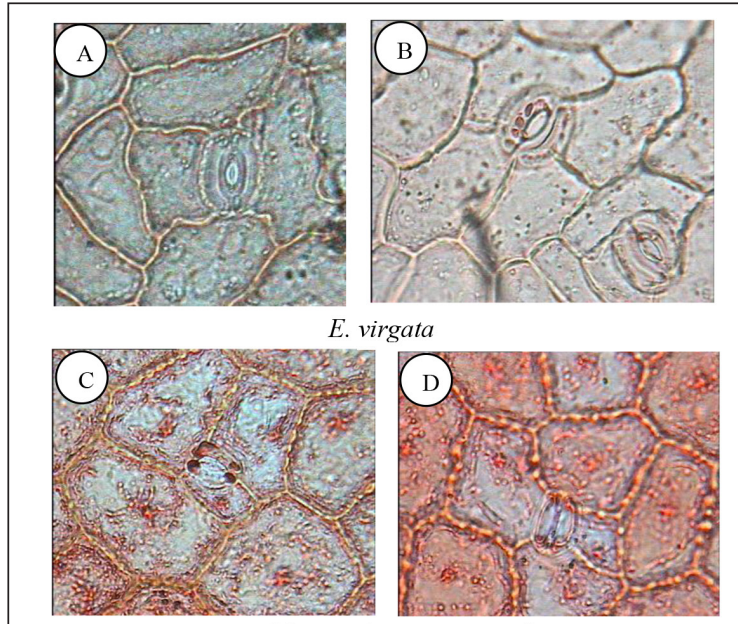

E. falcate subsp. macrostegia

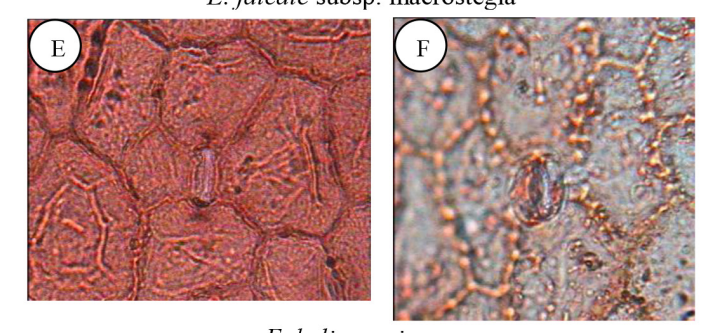

E. helioscopia

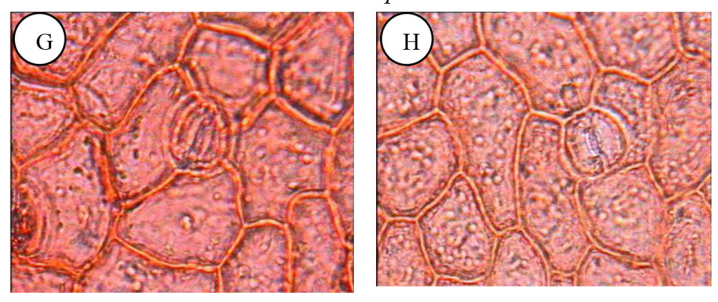

E. hebecarpa

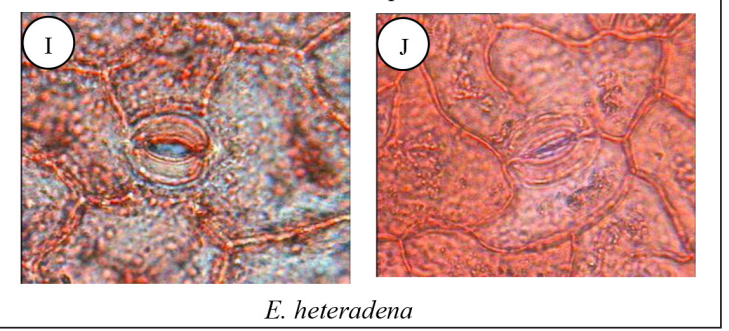

Fig. 2. A light photograph of leaf epidermis of the studied taxa (10X)

Previous studies show that different types of stomata are found in the members of Euphorbiaceae family (Metcalfe, Chalk, 1979). The study of 150 Euphorbia species showed that the majority of types of dicotyledon stomata present in this genus (Sehegal, Paliwal, 1974), the most important of which were anomo, aniso, para and cyclocytic (Kakkar, Paliwal, 1974).

Metcalfe and Chalk (1979) reported the presence of paracytic stomata in the tribe 

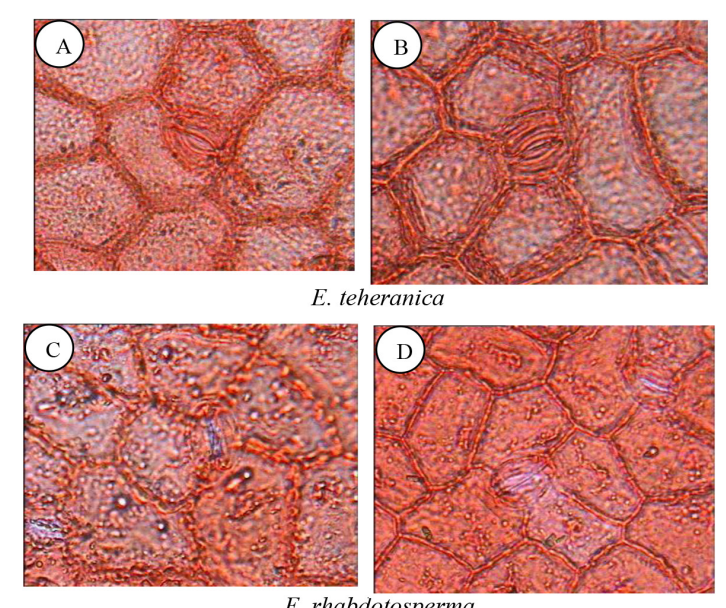

E. rhabdotosperma
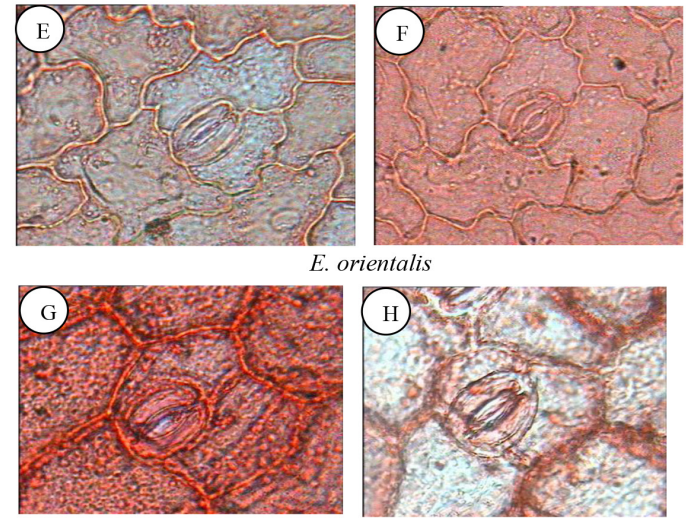

E. microsciadea

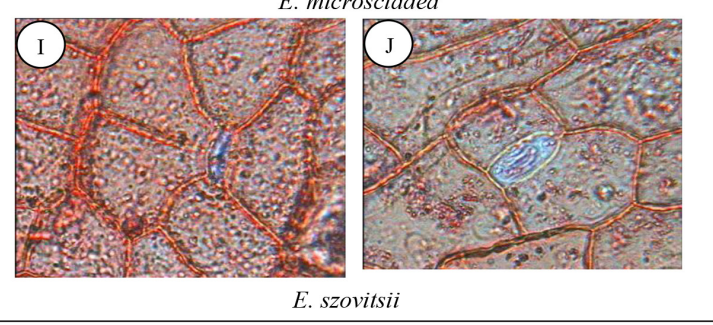

Fig. 3. A light photograph of leaf epidermis of the studied taxa (10X)

Euphorbieae and this is the most common type of stomata (Raju, Rao, 1977). Although stomata types in our studied species were similar in both adaxial and abaxial surfaces, in some species of this genus - E. gerardiana, E. exstipulata, E. mil$i$ i, E. arizonica, and E. bertheloti - more than one type of stomata were present on the same surface of the leaf (Kakkar, Paliwal, 1974).

Our findings showed that outer surfaces of the leaf of some species had trichomes. All observed trichomes were simple, uni- or multicelled and also non-branched. These results were in agreement with Gale and Toma (2006) and
Kakkar and Paliwal (1974). They found simple, unicellular or multicellular, uniseriate trichomes in Euphorbia species. For example, E. pulcherrima and E. prostrata have uniseriate and nonglandular trichomes (Zahra et al., 2014).

It seems that the absence/presence of trichomes is one of good characteristics for the identification of taxa and due to them the trichome-bearing species are easily distinguished from the rest. This idea was confirmed by studies on various taxa. For example, Vijay (1988) investigated leaf epidermal features of Indigofera. He found that these traits had a taxonomic significance, especially the structure, classification, and also organographic distribution of hairs that were important features in the recognition of these taxa. Studies of Bini Maleci and Servettaz (1991) confirmed that in Teucrium (Labiatae), the kind of glandular trichomes was used as a distinctive trait between the species; likewise, the glandular trichomes features in Calceolaria species could be important taxonomic tools.

In addition to taxonomic uses, trichomes have numerous ecological and physiological roles in a plant that help it to better establish itself in its habitat. Different investigations (for example, Wagner, 1991; Ascensão et al., 1999; Talebi et al., 2012; Werker, 2000), confirm that the main functions of glandular and non-glandular trichomes in plants are the reduction of the heat load, the increase of freezing tolerance, aid in seed dispersal, enhancement of water absorption, and protection of the structures of plants against the harmful effects of UV-B. They function as taxonomic characteristics, serve as an insect repellent, and offer a means of protection against herbivores and pathogens.

The shapes of epidermal cells varied between some of the studied taxa. All of our observations on epidermal cells were done on the middle parts of lamina, because the size, shape, and orientation of these cells vary considerably in various lamina parts of a single leaf. For instance, there are often distinct variations among epidermal cells overlying the veins and the cells located above the mesophyll between the veins (Metcalfe, Chalk, 1979). Therefore, the shapes of epidermal cells were useful taxonomic traits for the identification of some 

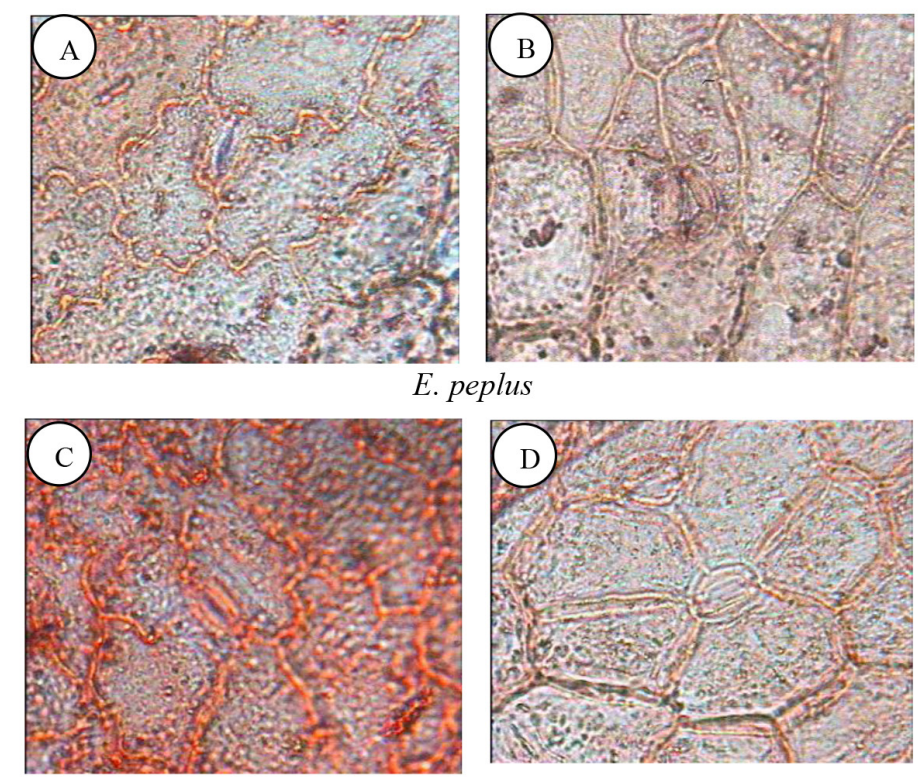

E. turcomanica

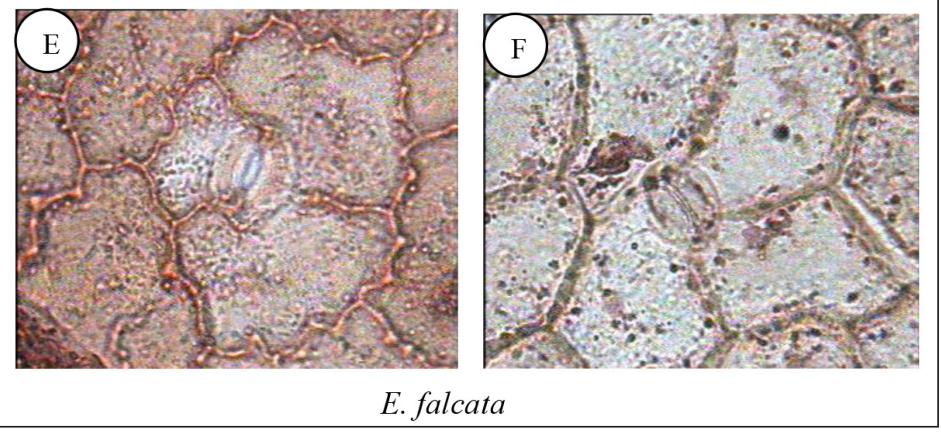

Fig. 4. A light photograph of leaf epidermis of the studied taxa (10X)
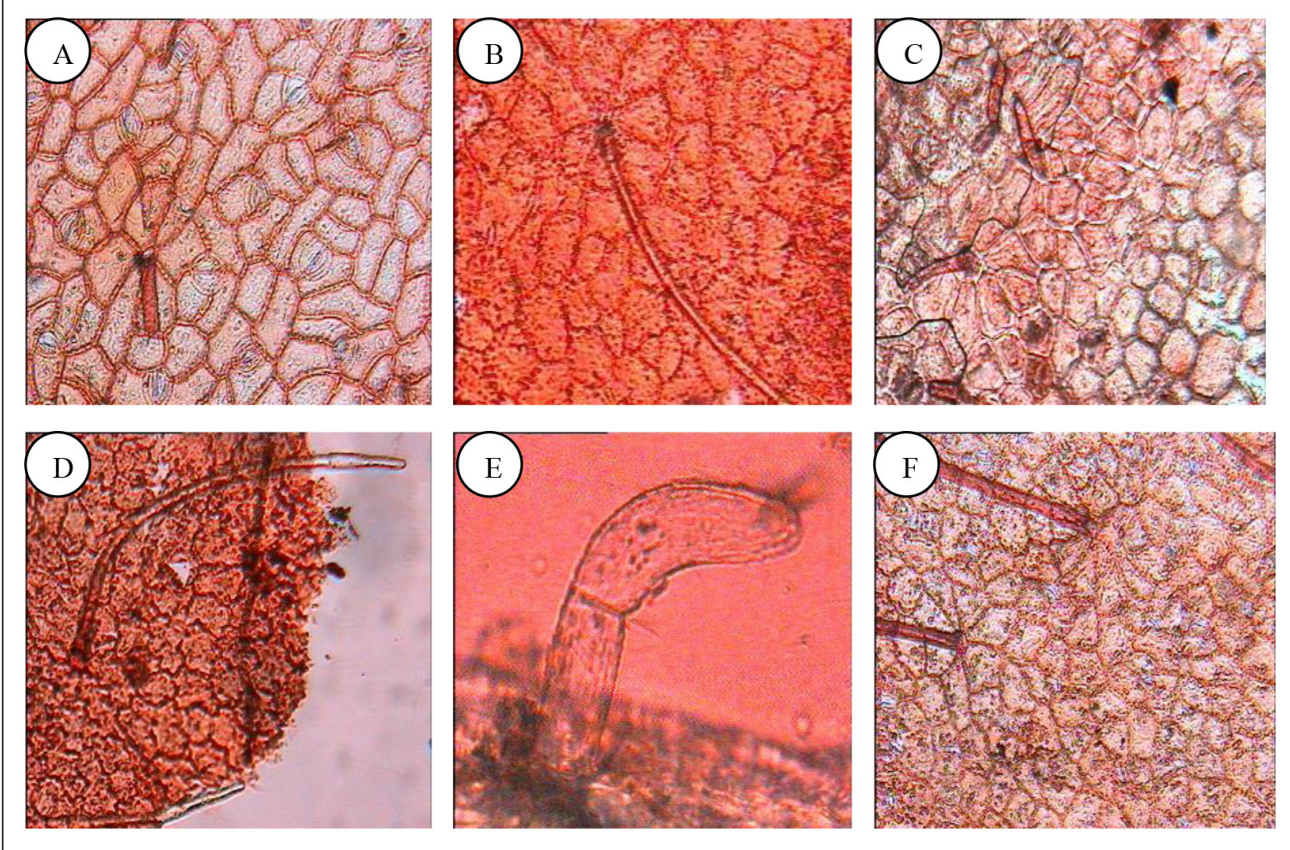

Fig. 5. Images of trichomes of the studied $\operatorname{taxa}(10 \mathrm{X})$

Abbreviations; A) E. connata, B) E. helioscopia, C) E. microsciadia, D, E) E. turcomanica, F) E. rhabdotosperma. 
species and for infraspecific classification. For example, two subspecies of $E$. falcata were easily distinguishable by the abaxial epiderm shape and the anticlinal cell wall pattern.

Our findings were in agreement with previous studies of Raju and Rao (2008). They investigated the shapes of leaf epidermal cells in Euphorbiaceae and stated that their shapes were polygonal, trapezoidal, or differently elongated in various directions, as well as diffusely arranged.

Although in most of the studied taxa the epidermal cells shapes in both abaxial and adaxial surfaces were the same, in some of them leaf epidermal shapes of abaxial and adaxial surfaces differed. This was a good characteristic feature for the identification of some taxa. For example, E. turcomanica, E. peplus, and E. falcata subsp. falcata were distinguished from the rest by the occurrence of heteromorphy in the cell shape of the two faces.

Studies show that this condition occurs in different species. For example, in Convolvulus arvensis L., Tribulus terristris L., Plantago ovate F., and Vicia faba L. the abaxial and adaxial surfaces of the same leaf were different (Ahmad et al., 2010). The cell wall pattern was another good anatomical feature for the separation of species. This feature was useful at two infra/ultra-sectional classifications.

\section{CONCLUSIONS}

Our findings show that the anatomical investigations of leaf epidermis reveals many interesting epidermal traits that have a taxonomic value. Previous investigations confirmed that different types of stomata were seen on the leaf surfaces of Euphorbia species, while in our studied taxa their types were identical and were not a good taxonomic feature. The absence/presence of trichomes was a good trait for identification of species in the genus. In addition, the pattern of distribution of hairs was a taxonomic tool in distinguishing the taxa, because their presence on leaf surfaces differed between trichomesbearing species. The shape of leaf epidermal cells and the pattern of their walls varied between some of the studied species. It is very important to know that in some species the shapes abaxial and adaxial surfaces differed. For this reason investigations of both leaf surfaces for the shape of epidermal cells and the wall pattern are very essential in the study of leaf anatomy of this genus.

Received 14 February 2017 Accepted 30 May 2017

\section{References}

1. Abubakar BY, Yunusa AI. Epidermal structure and stomata ontology as an aid to taxonomic identification of some species of Acasia (Legominose-Mimosoideae). Nigerian Journal of Botany. 1998; 11: 117-23.

2. Ahmad K, Khan M, Ahmad M, Shaheen N, Abdul Nazir A. Taxonomic diversity in epidermal cells of some sub-tropical plant species. Int J Agr Biol. 2010; 12: 115-8.

3. Ascensa o L, Mota L, Castro MDM. Glandular trichomes on the leaves and flowers of Plectranthus ornatus: morphology, distribution and histochemistry. Ann Bot. 1999; 84: 437-47.

4. Bartholott W. Epidermal and seed surface character of plant; systematic applicability and some evolutionary aspects. Nord J Bot. 1981; 1: 245-355.

5. Bini Maleci L, Servettaz O. Morphology and distribution of trichomes in Italian species of Teucrium sect. Chamaedrys (Labiatae) \pm a taxonomical evaluation. Plant Syst Evol. 1991; 174: 83-91.

6. Cutler DF. Leaf surface study in Aloe and Haworthia species (Liliaceae); taxonomic implications. Trop Subtrop Pflanzenwelt. 1979; 28: 8-29.

7. Evert RF. Esau's plant anatomy: meristems, cells, and tissues of plant body: their structure, function, and development. 3rd ed. Wiley Interscience Publication; 2006.

8. Frodin DG. History and concepts of big plant genera. Taxon. 2004; 53: 753-76.

9. Gale RC, Toma C. Comparative anatomy of the vegetative organs of some Euphorbia spe- 
cies (Euphorbiaceae Juss.) from the Romanian flora. Rom J Biol-Plant Biol. 2006; 51: 39-47.

10. Govaerts R, Frodin D, Radcliffe-Smith A. World checklist and bibliography of Euphorbiacea (with Pandaceae). Royal Botanic Gardens, Kew, 2000; 2: 417-921.

11. Kakkar L, Paliwal GS. Studies on leaf anatomy of Euphorbia L. V. Epidermis. Proc Indian Nat Sci Acad. 1974; 40: 55-67.

12. Metcalfe CR, Chalk L. Anatomy of the Dicotyledons, vol. 1. 2nd ed. London: Oxford University Press; 1979.

13. Ogunkunle ATJ, Oladele FA. Diagnostic value of trichomes in some Nigerian species of Ocimum. Hyptis Jazq. and Tinnea Kostschy and Peys (Lamiaceae). J Appl Sci. 2000; 3: 1163-80.

14. Raju SV, Rao PN. Variation in the structure and development of foliar stomata in the Euphorbiaceae. Bot J Linn Soc. 2008; 75: 69-97.

15. Raju VS, Rao PN. Variation in the structure and development of foliar stomata in the Euphorbiaceae. Bot J Linn Soc. 1977; 75: 69-97.

16. Rao PN, Raju VS. Foliar trichomes in the family Euphorbiaceae. Adv Plant Sci. 1985; 128-36.

17. Riina R, Peirson JA, Geltman DV, Molero J, Frajman B, Pahlevani A, Barres L, Morawetz JJ, Salmaki Y, Zarre S, Kryukov A, Bruyns PV, Berry PE. A worldwide molecular phylogeny and classification of the leafy spurges, Euphorbia subgenus Esula (Euphorbiaceae). Taxon. 2013; 62(2): 316-42.

18. Sehegal LS, Paliwal GS. Studies on the leaf anatomy of Euphorbia III the node. Bot J Linn Soc. 1974; 69: 37-43.

19. Talebi SM, Rezakhanlou A, Salahi Isfahani G. Trichomes plasticity in Ziziphora tenuior L. (Labiatae) in Iran: an ecological review Ann Biol Res. 2012; 3(1): 668-72.

20. Vijay Kumar BK. Structure, distribution and classification of plant trichomes in relation to taxonomy in Indigofera L. (Fabaceae). Indian J of Forestry. 1988; 11(2): 120-30.

21. Wagner GJ. Secreting glandular trichomes: more than just hairs. Plant Physiol. 1991; 96: 675-9.
22. Werker E. 2000. Trichome diversity and development. Adv Bot Res. 1991; 31: 1-35.

23. Widuri R, Van Welzen P. A revision of the genus Cephalomappa (Euphorbiaceae) in Malesia. Reinwardtia. 1998; 11(3): 153-84.

24. Zahra NB, Ahmad M, Shinwari ZK, Zafar M, Sultana SH. Systematic significance of anatomical characterization in some euphorbiaceous species. Pak J Bot. 2014; 46(5): 1653-61.

\section{Seyed Mehdi Talebi, Mitra Noori, Habibeh Afzali Naniz}

\section{KARPAŽOLĖS (EUPHORBIA) TAKSONŲ LAPU EPIDERMIO ANATOMIJOS TYRIMAS IŠ KERMANO PROVINCIJOS (IRANAS)}

\section{Santrauka}

Karpažolè (Euphorbia) yra didžiausia karpažolinių gentis, plačiai paplitusi visame pasaulyje. Ji natūraliai auga ịvairiose Irano dalyse, yra žinomos 96 karpažolių rūšys. Tyrimai rodo, kad lapijos epidermio savybès yra svarbios taksonams, todèl šio tyrimo metu buvo tirtos aštuoniolikos Euphorbia taksonų lapų epidermio anatomijos ypatybès. Kermano provincijoje (Iranas) surinkti augalų mėginiai buvo identifikuoti naudojantis prieinamomis nuorodomis. Paruošti lapo adaksialiniai ir abaksialiniai laikini mikroskopiniai preparatai buvo tiriami šviesiniu mikroskopu. Padarytos kiekvieno méginio mikrofotografijos. Rezultatai rodo, kad žiotelès tipas tarp rūšių buvo stabilus. Taksonai skyrèsi ne tik lapų epidermio ląstelemis, kai kuriose rūšyse kito abaksialinis ir adaksialinis paviršius. Kai kurie tirti taksonai turejjo paprastus ir nešakotus trichomus ant epidermio paviršiaus. Dažniausiai trichomai buvo ant abiejų lapo paviršių, o vienoje rūšyje jie pastebèti abaksialineje pusèje. Tyrimai patvirtino, kad kai kurios anatominès ypatybès, pavyzdžiui, trichomų buvimas arba nebuvimas ar epidermio ląstelių forma, buvo svarbūs taksonams ir yra naudingi jų identifikacijai.

Raktažodžiai: karpažolè, Euphorbia, lapo anatomija, epidermis, taksonomija 